\title{
Megjelent az Iskoláskorú gyermekek egészségmagatartása kutatás legújabb felmérésének nemzetközi jelentése
}

\author{
The latest report about the international study Health Behaviour in School- \\ aged Children
}

Szerző: $\quad$ Németh Ágnes $\square$

Nemzeti Egészségfejlesztési Intézet

Kulcsszavak: HBSC; egészségmagatartás; gyermek; serdülő; iskola

Keywords: HBSC; health behavior; child; adolescent; school

Az Emberi Erőforrások Minisztériumában (EMMI) 2016. március 17-én sajtótájékoztatót tartott Dr. Pusztai Zsófia, a WHO Magyarországi Irodájának vezetője, Dr. Török Krisztina, a Nemzeti Egészségfejlesztési Intézet főigazgatója és Dr. Beneda Attila, az EMMI egészségpolitikáért felelős helyettes államtitkára. A sajtótájékoztató témája az Iskoláskorú gyermekek egészségmagatartása (Health Behaviour in School-aged Children - HBSC) elnevezésű, az Egészségügyi Világszervezettel együttmúködésben megvalósuló, négy évenként felméréseket végző nemzetközi kutatás március 15-én megjelent nemzetközi és hazai jelentése volt, melyek a 2014-ben megvalósított legutóbbi adatfelvétel eredményeit mutatják be.

A felmérés 42, zömében európai ország több mint 220 ezer serdülőkorú fiataljának egészségére és életmódjára vonatkozó adatait gyűjtötte össze. Magyarországon az országosan reprezentatív vizsgálat keretében több mint hatezer 11, 13, 15 és 17 éves átlagéletkorú tanulót kérdeztek meg. A dohányzási és alkoholfogyasztási arányok a tinédzserek körében Magyarországon csökkentek 2010-hez képest. A Nemzeti Egészségfejlesztési Intézet által vezetett kutatás eredménye szerint a nemzetközi átlagokhoz képest viszont nem javultak eredményeink: még mindig kedvezőtlenebbek azoknál mind a dohányzás, mind az alkoholfogyasztás tekintetében. Minden ötödik magyar 15 éves hetente legalább egyszer rágyújt, míg Európában átlagban ez csak minden tizedik fiatalra jellemző. A magyar 15 évesek több mint egyharmada legalább kétszer volt már részeg életében és e tekintetben csak Dánia előzi meg hazánkat. Csökkentek a drogfogyasztási arányok is, a valamilyen szert életükben kipróbálók aránya jelenleg kevesebb, mint 25\%. A túlsúlyos magyar fiatalok aránya nem változott - mintegy 20\% a 11-15 évesek körében -, ez európai viszonylatban közepesnek mondható. A táplálkozási szokásokban azonban kedvező változást is tapasztaltunk: nőtt a zöldségféléket naponta fogyasztók száma, ez ebben a korosztályban minden harmadik magyar fiatalra jellemző. Kismértékben csökkent azoknak a száma is, akik naponta fogyasztanak cukortartalmú üdítőitalokat és édességeket. A fiatalok körében minden negyedik eszik rendszeresen ilyen terméket. A nemzetközi trendeket vizsgálva, ezen a területen hazánk több mint 30 európai országból a hetedik legdinamikusabban fejlődő ország közé tartozik. Mérsékelt, de egyértelmúen javuló tendencia látható a testmozgás gyakoriságában: a semmit vagy nagyon keveset mozgó tanulók aránya csökkent, jelenleg $28 \%$. Némileg csökkent a sokat, naponta legalább 2 órát televíziót nézők aránya; hétköznapokon több mint a tanulók fele, hétvégén 80\%-a tölti ezzel az idejét. A magyar fiatalok nemzetközi viszonylatban magas arányban értékelik egészségüket rossznak vagy éppen csak megfelelőnek. A gyakori egészségpanaszok (pl. fejfájás, gyomorfájás, ingerlékenység, fáradtság, elalvási nehézségek) előfordulása azonban átlagosnak mondható Európában. Hazánkban egyedülálló módon vizsgáljuk a serdülőkorúak hangulati problé- 
máit, depresszív érzéseit is. E tekintetben kedvezőtlen változást tapasztaltunk: 2010-ben a 15 éveseknek mintegy egynegyede, 2014-ben azonban már közel egyharmada számolt be hangulati zavarokról. Első ízben vizsgálta a kutatás a tizenévesek baráti kapcsolatainak erősségét. E tekintetben hazánk kiemelkedően jó eredményeket mutat: a 11 és 13 évesek körében a magyar tanulók számoltak be a legnagyobb arányban erős baráti támogatásról, míg a 15 évesek között csak a svájci fiatalok előzik meg a magyarokat. A magas társas támogatottság a tanulók több mint háromnegyedére jellemző minden korcsoportban.

A nemzetközi angol nyelvú jelentés elektronikusan elérhető, a hazai kutatási jelentés pedig hamarosan olvasható lesz a NEFI honlapján. 